\title{
COVID-19 outcomes in MS
}

\section{Observational study of early experience from NYU Multiple Sclerosis Comprehensive Care Center}

Erica Parrotta, DO, Ilya Kister, MD, Leigh Charvet, PhD, Carrie Sammarco, DNP, Valerie Saha, NP, Robert Erik Charlson, MD, Jonathan Howard, MD, Josef Maxwell Gutman, MD, Malcolm Gottesman, MD, Nada Abou-Fayssal, MD, Robyn Wolintz, MD, Marshall Keilson, MD, Cristina Fernandez-Carbonell, MD, Lauren B. Krupp, MD, and Lana Zhovtis Ryerson, MD

Neurol Neuroimmunol Neuroinflamm 2020;7:e835. doi:10.1212/NXI.0000000000000835

\section{Abstract}

\section{Objective}

To report outcomes on patients with multiple sclerosis (MS) and related disorders with coronavirus disease 2019 (COVID-19) illness.

\section{Methods}

From March 16 to April 30, 2020, patients with MS or related disorders at NYU Langone MS Comprehensive Care Center were identified with laboratory-confirmed or suspected COVID19. The diagnosis was established using a standardized questionnaire or by review of in-patient hospital records.

\section{Results}

We identified 76 patients (55 with relapsing MS, of which 9 had pediatric onset; 17 with progressive MS; and 4 with related disorders). Thirty-seven underwent PCR testing and were confirmed positive. Of the entire group, 64 (84\%) patients were on disease-modifying therapy (DMT) including anti-CD20 therapies $(\mathrm{n}=34,44.7 \%)$ and sphingosine-1-phosphate receptor modulators $(\mathrm{n}=10,13.5 \%)$. The most common COVID-19 symptoms were fever and cough, but $21.1 \%$ of patients had neurologic symptom recrudescence preceding or coinciding with the infection. A total of 18 (23.7\%) were hospitalized; 8 (10.5\%) had COVID-19 critical illness or related death. Features more common among those hospitalized or with critical illness or death were older age, presence of comorbidities, progressive disease, and a nonambulatory status. No DMT class was associated with an increased risk of hospitalization or fatal outcome.

\section{Conclusions}

Most patients with MS with COVID-19 do not require hospitalization despite being on DMTs. Factors associated with critical illness were similar to the general at-risk patient population. DMT use did not emerge as a predictor of poor COVID-19 outcome in this preliminary sample.

\author{
Correspondence \\ Dr. Zhovtis Ryerson \\ lana.zhovtisryerson@ \\ nyulangone.org
}

MORE ONLINE

COVID-19 Resources

For the latest articles, invited commentaries, and blogs from physicians around the world NPub.org/COVID19

From the NYU Langone Multiple Sclerosis Comprehensive Care Centers (E.P., I.K., L.C., C.S., V.S., R.E.C., J.H., J.M.G., M.G., N.A.-F., R.W., M.K., L.B.K., L.Z.R.), New York, NY; and Cohen's Children Medical Center Northwell Health (C.F.-C.), Lake Success, NY.

Go to Neurology.org/NN for full disclosures. Funding information is provided at the end of the article.

The Article Processing Charge was funded by the authors.

This is an open access article distributed under the terms of the Creative Commons Attribution-NonCommercial-NoDerivatives License 4.0 (CC BY-NC-ND), which permits downloading and sharing the work provided it is properly cited. The work cannot be changed in any way or used commercially without permission from the journal. 


\section{Glossary}

CAD = coronary artery disease COVID-19 = coronavirus disease 2019; DMT = disease-modifying therapy; ICU = intensive care unit.

At present, we do not know whether multiple sclerosis (MS) or disease-modifying therapies (DMTs) for MS increase the risk of acquiring coronavirus disease 2019 (COVID-19) or worsen the course (hospitalizations, intensive care unit [ICU], and death). DMT medications have immunosuppressive effects that could hamper mounting an effective immune response to the infection. ${ }^{1}$ On the other hand, immunosuppression could offer protection by downregulating hyperinflammation and the cytokine storm associated with COVID-19. ${ }^{2}$

New York City emerged as the epicenter of the COVID-19 pandemic in the United States in March 2020. Given the widespread prevalence of COVID-19 in our community, clinicians at the NYU Multiple Sclerosis Comprehensive Care Center (MSCCC) received numerous reports of Severe Acute Respiratory Syndrome Coronavirus 2 (SARS-COV2) infection from patients and began systematically collecting symptom data and the clinical course. This timely, real-world observational study on outcomes of COVID-19 in actively treated patients with MS help inform clinicians as they counsel patients with MS and guide treatment decisions during the pandemic.

\section{Methods}

For this observational study, demographic and clinical features were collected on patients currently followed at MSCCC and its 4 affiliated sites in the greater New York area ( 2 in Long Island and 2 in Brooklyn) with a history of COVID-19 from March 16 through April 30, 2020. All patients who contacted the center with infectious symptoms or were seen during routine teleneurology visits were queried regarding COVID-19 exposure using a standardized instrument. Inclusion criteria were any patient with MS or related disorders who was diagnosed with COVID-19 by a health care provider (based on symptoms, course, radiographic findings consistent with CDC COVID-19 criteria, ${ }^{3}$ and/or positive SARS-COV2 PCR when available). For hospitalized patients, in-patient records were reviewed. NYU School of Medicine Institutional Review Board approval was obtained for the study.

Descriptive statistics were used to summarize the demographic and clinical characteristics of patient. Continuous variables were described in terms of means and SDs, and categorical variables were summarized as counts and percentages. No imputation was made for missing data. Differences between hospitalized vs nonhospitalized patients were compared by the $t$ test, $\chi^{2}$ test, or Fisher exact test as indicated, with CIs set at $95 \%$.

\section{Data availability}

Anonymized data can be made available on request for research purposes by submitting a request to the corresponding author. No deidentified patient data or study-related documents will be shared.

\section{Results}

A total of 76 patients met the inclusion criteria, 72 (93\%) with MS, and 4 (7\%) with related disorders (neuromyelitis optica spectrum disorder, chronic relapsing inflammatory optic neuropathy, neurosarcoidosis, and myelin oligodendrocyte glycoprotein-immunoglobulin G-associated disorder). The average age of the full sample was $44.9 \pm 15.2$ years (range $13-71$ years), and $61.8 \%$ were female. The disease duration was $15.2 \pm 10.7$ years (range $1-52$ years). Racial breakdown was 50 (65.8\%) white, 21 (27.6\%) black, 3 (3.9\%) Asian, 1 (1.3\%) Pacific Islander, and 1 (1.3\%) other. Hispanic ethnicity was reported by $15(19.7 \%)$. Of the 72 patients with MS, 55 $(76.4 \%)$ had a relapsing-remitting subtype and 17 (23.6\%) primary or secondary progressive subtypes. Sixty-five patients (84\%) were on DMT. One patient resided in a nursing facility. He had an uncomplicated course.

Common symptoms reported included fever (68.4\%), cough (68.4\%), fatigue (38.2\%), shortness of breath $(31.6 \%)$, and myalgias/arthralgias (26.3\%). Other frequent symptoms included anosmia (22\%), ageusia (19.7\%), and headache (21.1\%). A subset reported neurologic symptom recrudescence (21.1\%) suggestive of relapse. In some cases, neurologic symptoms preceded viral symptoms by several days.

Of the $84 \%$ of patients on DMTs, $44.7 \%$ were treated with antiCD20 therapies (rituximab $n=18$; ocrelizumab $n=16$ ), $13.5 \%$ on sphingosine-1-phosphate (S1P) modulators (fingolimod $\mathrm{n}$ $=8$; siponimod $\mathrm{n}=2), 7.9 \%(\mathrm{n}=6)$ on glatiramer acetate, $5.3 \%$ $(n=4)$ each on natalizumab and dimethyl fumarate, and 3.9\% $(\mathrm{n}=3)$ on beta-interferons. Table 1 summarizes outcomes by DMT class. There were no observed differences between DMT use among those who were and were not hospitalized or between those specifically treated with anti-CD20 therapies (43\% vs $50 \%$, OR $=0.76$ [CI 0.26-2.18]).

As shown in table 2, of the full sample, 18 (23.7\%) were hospitalized. The hospitalized vs nonhospitalized patients were more likely to be older (CI 1.22-17.11, $p=0.03$ ), have progressive MS subtype (OR 4.11 [CI 1.21-13.97], $p=0.04$ ), required ambulatory assistance or were nonambulatory (OR 4.27 [CI 1.38-13.27], $p=0.01$ ), and have comorbid obesity (OR 6.25 [CI 1.90-20.50], $p=0.003)$. Coronary artery disease (CAD) was observed in $\mathrm{n}=3$ hospitalized patients and no cases in nonhospitalized patients. 
Table 1 Disease-modifying therapy specific outcomes

\begin{tabular}{|c|c|c|c|c|c|c|c|c|}
\hline Demographics & Anti-CD20 & S1P inhibitors & Glatiramer acetate & Natalizumab & Dimethyl fumarate & Interferon & IVIG & None \\
\hline & 34 & 10 & 6 & 4 & 4 & 3 & 3 & 12 \\
\hline Age, years (SD) & 38.72 (SD 14.9) & 44.90 (SD 11.2) & 53.3 (SD 14.8) & 37.8 (SD 17.9) & $52.8(\mathrm{SD} 7.2)$ & 57.6 (SD 16.7) & 57 (SD 12.8) & 49.8 (SD 15.8) \\
\hline emale $\mathbf{n}(\%)$ & $20(62.5 \%)$ & $6(60 \%)$ & $4(66.7 \%)$ & $2(50 \%)$ & $2(50 \%)$ & $1(33.3 \%)$ & $3(100 \%)$ & $8(66.7 \%)$ \\
\hline \multicolumn{9}{|l|}{ Ambulation status, $n$ (\%) } \\
\hline Ambulatory & $27(79.4 \%)$ & $9(90 \%)$ & $2(33.3 \%)$ & $4(100 \%)$ & $3(75 \%)$ & $3(100 \%)$ & - & $8(66.7 \%)$ \\
\hline Ambulatory with assistance & $4(11.8 \%)$ & $1(10 \%)$ & $3(50 \%)$ & - & - & - & $2(66.7 \%)$ & $1(8.3 \%)$ \\
\hline Nonambulatory & $3(8.8 \%)$ & - & $1(16.7 \%)$ & - & $1(25 \%)$ & - & $1(33.3 \%)$ & $3(25 \%)$ \\
\hline \multicolumn{9}{|l|}{ tospitalization } \\
\hline Not hospitalized & $25(73.5 \%)$ & $9(90 \%)$ & $5(83.3 \%)$ & $3(75 \%)$ & $2(50 \%)$ & $3(100 \%)$ & $3(100 \%)$ & $8(66.7 \%)$ \\
\hline Hospitalized & $9(26.5 \%)$ & $1(10 \%)$ & $1(16.7 \%)$ & $1(25 \%)$ & $2(50 \%)$ & - & - & $4(33.3 \%)$ \\
\hline \multicolumn{9}{|l|}{ Eomorbidities associated with COVID-19 } \\
\hline Obesity & $9(26.5 \%)$ & $3(30 \%)$ & $2(33.3 \%)$ & $2(50 \%)$ & $1(25 \%)$ & - & $1(33.3 \%)$ & $6(50 \%)$ \\
\hline Hypertension & $4(11.8 \%)$ & $3(30 \%)$ & $1(16.7 \%)$ & $1(25 \%)$ & $2(50 \%)$ & - & $2(66.7 \%)$ & $4(33.3 \%)$ \\
\hline Diabetes & $1(2.9 \%)$ & $1(10 \%)$ & $1(16.7 \%)$ & $1(25 \%)$ & $1(25 \%)$ & - & $1(33.3 \%)$ & $2(16.7 \%)$ \\
\hline CAD & $1(2.9 \%)$ & - & $1(16.7 \%)$ & $1(25 \%)$ & - & - & - & - \\
\hline \multicolumn{9}{|l|}{ OOVID-19 outcomes } \\
\hline Death & $2(5.8 \%)$ & - & $1(16.7 \%)$ & $1(25 \%)$ & - & - & - & $2(16.7 \%)$ \\
\hline Ongoing treatment/still recovering & $8(23.5 \%)$ & $3(30 \%)$ & $1(16.7 \%)$ & - & - & - & $1(33.3 \%)$ & $2(16.7 \%)$ \\
\hline Recovered & $24(70.6 \%)$ & $7(70 \%)$ & $4(66.7 \%)$ & $3(75 \%)$ & $4(100 \%)$ & $3(100 \%)$ & $2(66.7 \%)$ & $8(66.7 \%)$ \\
\hline
\end{tabular}

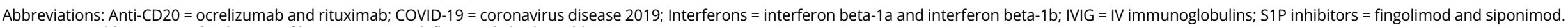
One 58-year-old woman with a history of hypertension on leflunomide had a mild course. 
Table 2 Demographics of hospitalized vs nonhospitalized patients with COVID-19

\begin{tabular}{|c|c|c|}
\hline Demographics & Hospitalized $(n=18)$ & Nonhospitalized $(n=58)$ \\
\hline Age, years (range, SD) & $52.0(17-71,14.6)$ & $42.7(13-71,14.8)$ \\
\hline Sex (\% female) & $10(55.6 \%)$ & $37(63.8 \%)$ \\
\hline Race, n (\% white) & $12(66.7 \%)$ & $38(65.5 \%)$ \\
\hline Ethnicity, n (\% Hispanic) & $6(33.3 \%)$ & $9(15.5 \%)$ \\
\hline \multicolumn{3}{|l|}{ Clinical diagnosis } \\
\hline RRMS & $8(44.4 \%)$ & $47(81.0 \%)$ \\
\hline Progressive MS & $7(38.8 \%)$ & $10(17.2 \%)$ \\
\hline Other demyelinating syndrome & $3(16.7 \%)$ & $1(1.7 \%)$ \\
\hline Disease duration, years (range, SD) & $17.2(5-36,10.5)$ & $14.6(1-52,10.8)$ \\
\hline \multicolumn{3}{|l|}{ Ambulation status, $\mathbf{n}(\%)$} \\
\hline Ambulatory & $9(50 \%)$ & $47(81 \%)$ \\
\hline Ambulatory with assistance & $5(27.8 \%)$ & $6(10.3 \%)$ \\
\hline Nonambulatory & $4(22.2 \%)$ & $5(8.6 \%)$ \\
\hline \multicolumn{3}{|l|}{ Comorbidities associated with COVID-19 } \\
\hline Obesity & $11(61 \%)$ & $12(20.7 \%)$ \\
\hline Hypertension & $5(27.8 \%)$ & $12(20.6 \%)$ \\
\hline CAD & $3(16.6 \%)$ & - \\
\hline Diabetes & $2(11.1 \%)$ & $6(10.3 \%)$ \\
\hline Venous thromboembolism & $3(16.6 \%)$ & $1(1.7 \%)$ \\
\hline \multicolumn{3}{|l|}{ COVID-19 outcomes } \\
\hline Death, n (\%) & $5(27.7 \%)$ & $1(1.7 \%)$ \\
\hline Ongoing treatment/still recovering & $4(22.2 \%)$ & $10(17.2 \%)$ \\
\hline Recovered, n (\%) & $9(50.0 \%)$ & $47(81.0 \%)$ \\
\hline
\end{tabular}

Abbreviations: $C A D$ = coronary artery disease; COVID-19 = coronavirus disease 2019; DMT = disease-modifying therapy.

History of venous thromboembolism was recorded in $\mathrm{n}=3$ hospitalized and $\mathrm{n}=1$ nonhospitalized patient.

Eight patients (10.5\%) had critical illness defined by ICU admission $(\mathrm{n}=5)$ and/or death $(\mathrm{n}=6)($ table 3$)$. Compared with the entire MS sample, the critically ill patients were older (mean of 57.7 \pm 10.5 years, range $42-71$ years), more likely to have a progressive subtype (50.0\%), and or required assistance for ambulation/ nonambulatory (62.5\% requiring assistance or nonambulatory). Following the pattern observed in those who were hospitalized, the critically ill group had had high rates of comorbid obesity $(62.5 \%)$, CAD (25\%), and venous thromboembolism (37.5\%). There were no reports of stroke. One patient had hypercoagulability resulting in multiple venous thromboembolisms and ultimately died.

Nine patients with pediatric-onset MS were identified as the center has a large pediatric MS sample (table 4). Ages ranged from 13 to 26 years; 8 were female, and all had relapsing-remitting MS. Noted comorbidities were obesity $(n=3)$, type I diabetes $(n=1)$, or both $(n=1)$. Two of the 9 were hospitalized requiring supplemental oxygen. None required invasive ventilation. Eight patients were either fully recovered or recovering at censoring date. One remains hospitalized.

\section{Discussion}

Patients with MS and related disorders often seek guidance regarding the impact of the disease and medication on their risk of COVID-19. This observational study-although subject to sampling and ascertainment biases-provides some insights regarding COVID-19 disease course in actively treated patients with MS and related disorders.

The rate of hospitalization in our patients (24\%) and mortality (7.9\%) are in line with the data of another published MS 
Table 3 Critically ill and deceased patient outcomes

\begin{tabular}{|c|c|c|c|c|c|}
\hline $\begin{array}{l}\text { Race/ } \\
\text { ethnicity }\end{array}$ & $\begin{array}{l}\text { Diagnosis and } \\
\text { disease duration } \\
\text { (y) }\end{array}$ & DMT & $\begin{array}{l}\text { Ambulation } \\
\text { status }\end{array}$ & Comorbidities & COVID course and outcome \\
\hline $\begin{array}{l}\text { Black/non- } \\
\text { Hispanic }\end{array}$ & RRMS-18y & Rituximab & Nonambulatory & $\begin{array}{l}\text { Chronic anticoagulation for VTE, Hodgkin } \\
\text { lymphoma, and ITB }\end{array}$ & $\begin{array}{l}\text { Several weeks of fevers, cough, and dyspnea. A family member in the home } \\
\text { was also sick with similar symptoms. Died at home. }\end{array}$ \\
\hline $\begin{array}{l}\text { Black/non- } \\
\text { Hispanic }\end{array}$ & SPMS-26y & None & Nonambulatory & $\begin{array}{l}\text { Diabetes, morbid obesity, hypertension, chronic } \\
\text { anticoagulation for VTE, and hyperlipidemia }\end{array}$ & $\begin{array}{l}\text { Hospitalized with dyspnea, fever, and cough and received high-flow oxygen. } \\
\text { Discharged to a rehabilitation facility on supplemental oxygen }\end{array}$ \\
\hline $\begin{array}{l}\text { White/non- } \\
\text { Hispanic }\end{array}$ & RRMS-13 y & None & Ambulatory & Hypertension, obesity, and hypothyroid & $\begin{array}{l}\text { Hospitalized with respiratory failure following treatment with } 5 \mathrm{~d} \text { of IVMP for } \\
\text { MS exacerbation. Received ventilator and ECMO support. Deceased. }\end{array}$ \\
\hline $\begin{array}{l}\text { Black/non- } \\
\text { Hispanic }\end{array}$ & RRMS-19y & Natalizumab & Ambulatory & CAD with cardiac stents, hypertension, and obesity & $\begin{array}{l}\text { Hospitalized with fatigue, cough, fever, and respiratory failure. Found to have } \\
\text { DVT and PE. Had cardiac arrest. Deceased. }\end{array}$ \\
\hline $\begin{array}{l}\text { White/ } \\
\text { Hispanic }\end{array}$ & NMOSD-7y & Rituximab & Ambulatory & Obesity & $\begin{array}{l}\text { Hospitalized with dyspnea and fever and on high-flow oxygen. Remains } \\
\text { hospitalized. }\end{array}$ \\
\hline $\begin{array}{l}\text { White/non- } \\
\text { Hispanic }\end{array}$ & SPMS-31 y & None & Nonambulatory & ITB and neurogenic bladder with indwelling Foley & Hospitalized with fever, dyspnea, and code status DNR/DNI. Deceased \\
\hline $\begin{array}{l}\text { White/non- } \\
\text { Hispanic }\end{array}$ & SPMS-33 y & Ocrelizumab & Nonambulatory & $\begin{array}{l}\text { Remote history of testicular and prostate cancer } \\
\text { and ITB }\end{array}$ & $\begin{array}{l}\text { Hospitalized with respiratory failure and received ventilator support. } \\
\text { Deceased. }\end{array}$ \\
\hline $\begin{array}{l}\text { Black/non- } \\
\text { Hispanic }\end{array}$ & SPMS-30 y & $\begin{array}{l}\text { Glatiramer } \\
\text { acetate }\end{array}$ & $\begin{array}{l}\text { Ambulatory } \\
\text { with assistance }\end{array}$ & Chronic anticoagulation for VTE obesity & Hospitalized with dyspnea and fever and had cardiac arrest. Deceased. \\
\hline
\end{tabular}

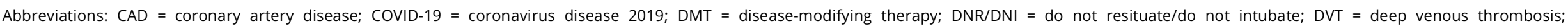

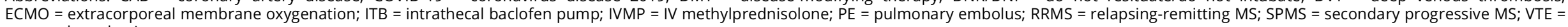
venous thrombosis.

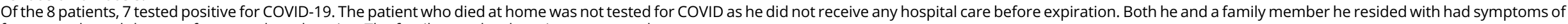
fever, cough, and dyspnea for several weeks prior. The family member has since recovered. 
Table 4 Demographics of patients with pediatric-onset MS with COVID-19

\begin{tabular}{|c|c|}
\hline & $\begin{array}{l}\text { Full sample } \\
(n=9)\end{array}$ \\
\hline \multicolumn{2}{|l|}{ Demographics } \\
\hline Age, years (range, SD) & $\begin{array}{l}19.44(13-26 \\
4.12)\end{array}$ \\
\hline Sex (\% female) & $7(77.7 \%)$ \\
\hline Race, n (\% white) & $6(66.6 \%)$ \\
\hline Ethnicity, n (\% Hispanic) & $5(55.5 \%)$ \\
\hline \multicolumn{2}{|l|}{ Clinical history } \\
\hline MS subtype, n (\% RRMS) & $9(100 \%)$ \\
\hline Disease duration, years (range, SD) & $6.11(2-12,3.55)$ \\
\hline \multicolumn{2}{|l|}{ DMT, n (\%) } \\
\hline Glatiramer & $1(11.1 \%)$ \\
\hline Ocrelizumab & $2(22.2 \%)$ \\
\hline Rituximab & $4(44.4 \%)$ \\
\hline Natalizumab & $1(11.1 \%)$ \\
\hline None & $1(11.1 \%)$ \\
\hline Ambulation status, $\mathrm{n}$ (\% fully ambulatory) & $9 \%(100)$ \\
\hline \multicolumn{2}{|l|}{$\begin{array}{l}\text { COVID-19 testing, comorbidities, and } \\
\text { hospitalization }\end{array}$} \\
\hline Tested for COVID-19, n (\%) & $5(55.5 \%)$ \\
\hline Positive, n (\% tested) & $4(80 \%)$ \\
\hline Diabetes, type I & $2(22.2 \%)$ \\
\hline Obesity & $3(33.3 \%)$ \\
\hline Asthma & $1(11.1 \%)$ \\
\hline Hospitalized, n (\%) & $2(22.2 \%)$ \\
\hline
\end{tabular}

Abbreviation: DMT = disease-modifying therapy.

patient survey ${ }^{4}$ and for the general population of patients with COVID-19. ${ }^{5}$ Similar risk factors were identified including older age, male sex, and high number of comorbidities such as obesity, diabetes, hypertension, and CAD. ${ }^{6-8}$ MS-specific features associated with more severe COVID-19 included nonambulatory status and progressive disease course. Given the small sample size, we could not determine whether these patients were at higher risk, given their advanced age and other comorbidities, or whether worse disability in and of itself represents an additional risk factor.

We did not observe an association between DMT class and COVID-19 outcome in univariate comparisons; however, our sample size is small, and these preliminary findings should be interpreted with caution. There is a relatively high proportion of COVID-19-infected patients on anti-CD20 therapies (44.7\%) compared with our MSCCC population in which $33.1 \%$ of patients take anti-CD20 therapies. This observation could be an artifact of sampling bias or might represent an increased susceptibility to COVID-19 infection as anti-CD-20 therapies increase the risk of non-COVID-19 infections in general. ${ }^{1}$ It is worth noting that although we had a larger-thanexpected portion of patients on anti-CD20 therapies, there is no evidence to suggest worse outcomes.

As a note of caution in the care of patients with MS, a subgroup of individuals reported worsening of preexisting neurologic symptoms before or at onset of COVID-19 symptoms. One such patient was treated with several days of high-dose steroids after which they presented with respiratory and circulatory failure and ultimately died (table 3 ). Infections are a well-known cause of pseudoexacerbations, and in areas with high prevalence of COVID-19, testing for SARS-COV2 should be considered in patients with acute worsening of preexisting symptoms before steroid treatment is initiated.

Our study has several limitations. This was a convenience sample and not randomly selected, nor was the entire practice systematically surveyed. Patients were identified during routine teleneurology visits, if they notified the office, or if hospitalized-likely leading to an overrepresentation of more symptomatic individuals. Patients on higher potency infusible DMTs were more likely to have frequent follow-up and may have been more readily captured. In contrast, patients in nursing homes, who would be expected to be most severely affected by COVID-19, visit specialized centers less frequently and could be underrepresented in our cohort. Although we used a systematic questionnaire to collect relevant data, we could not verify these data independently unless the patient was seen by an NYU Langone-affiliated physician or hospital. Another problem was lack of access to COVID-19 testing in our area. Less than half of our patients (48.7\%) underwent SARS-COV2 PCR testing. As shown in table 5 , subgroup analysis showed that this group was not different from the overall sample with respect to demographic or MS-related features.

Our early experience with COVID-19 at NYU Langone MSCCC could inform clinicians taking care of patients with MS during the pandemic. Our findings suggest that individuals with MS who experience COVID-19 have similar disease course, outcomes, and risk factors for complications as the general population. Rigorous, population-based studies are needed to confirm our preliminary findings and better define the risk of COVID-19 infection with respect to individual DMTs. Future studies should assess the role of baseline lymphocyte counts and immunoglobulin levels with respect to viral susceptibility and course as well as examine the frequency of serologies to COVID-19 according to DMT class. As we and others collect more data and contribute to larger MS registries, we expect more answers will be forthcoming to further guide patient management. 
Table 5 Demographics and outcomes of all patients vs COVID-19 PCR confirmed positive

$$
\text { All patients }(n=76)
$$

COVID PCR positive $(n=37)$

\section{Demographics}

Age, years (range, SD)

$44.9(13-71,15.2)$

$47.5(13-71,15.15)$

Sex, F/M (\% female)

$47 / 29(61.8 \%)$

$23 / 14(62.2 \%)$

Race, $\mathbf{n}$ (\%)

White

$50(65.8 \%)$

$24(64.9 \%)$

Black

$21(27.6 \%)$

$12(32.4 \%)$

Asian

Pacific Islander

$3(3.9 \%)$

$1(1.3 \%)$

Other

$1(1.3 \%)$

一

$-$

thnicity, $n(\%)$

\begin{tabular}{llc}
\hline Non-Hispanic & $59(77.6 \%)$ & $28(75.7 \%)$ \\
\hline Hispanic & $15(19.7 \%)$ & $8(21.6 \%)$ \\
\hline Other & $2(2.6 \%)$ & $1(2.7 \%)$ \\
\hline Smoking status, $\mathbf{n}(\%)$ & & $25(67.5 \%)$ \\
\hline Never & $52(68.4 \%)$ & $10(27.02)$ \\
\hline Former & $20(26.3 \%)$ & $1(2.7 \%)$ \\
\hline Current & $2(2.6 \%)$ & $1(2.7 \%)$ \\
\hline Unknown & $2(2.6 \%)$ & \\
\hline
\end{tabular}

Clinical

MS, n (\%)

\begin{tabular}{|c|c|c|}
\hline RRMS & $55(72.3 \%)$ & $25(67.6 \%)$ \\
\hline SPMS & $15(19.7 \%)$ & $10(27.0 \%)$ \\
\hline PPMS & $2(2.6 \%)$ & - \\
\hline Other demyelinating syndrome, $n$ (\%) & $4(5.2 \%)$ & $2(5.4 \%)$ \\
\hline Disease duration, years (range, SD) & $15.2(1-52,10.7)$ & $16.9(2-52,11.46)$ \\
\hline \multicolumn{3}{|l|}{ DMT, n (\%) } \\
\hline Anti-CD20 & $34(44.7 \%)$ & $14(37.8 \%)$ \\
\hline S1P Inhibitors & $10(13.2 \%)$ & $4(10.8 \%)$ \\
\hline Glatiramer acetate & $6(7.9 \%)$ & $4(10.8 \%)$ \\
\hline Natalizumab & $4(5.3 \%)$ & $3(8.1 \%)$ \\
\hline Dimethyl fumarate & $4(5.3 \%)$ & $2(5.4 \%)$ \\
\hline Leflunomide & $1(1.3 \%)$ & $1(2.7 \%)$ \\
\hline Interferons & $3(3.9 \%)$ & $1(2.7 \%)$ \\
\hline IVIG & $3(3.9 \%)$ & $1(2.7 \%)$ \\
\hline None & $12(15.8 \%)$ & $7(18.9 \%)$ \\
\hline \multicolumn{3}{|l|}{ Ambulation status, $\mathbf{n}(\%)$} \\
\hline Ambulatory & $56(73.7 \%)$ & $24(64.9 \%)$ \\
\hline Ambulation with assistance & 11 (14.4\%) & 7 (18.9\%) \\
\hline
\end{tabular}


Table 5 Demographics and outcomes of all patients vs COVID-19 PCR confirmed positive (continued)

\begin{tabular}{|c|c|c|}
\hline & All patients $(n=76)$ & COVID PCR positive $(n=37)$ \\
\hline Nonambulatory & $9(11.8 \%)$ & $6(16.2 \%)$ \\
\hline \multicolumn{3}{|l|}{ Comorbidities associated with COVID-19 } \\
\hline Hypertension & $17(22.4 \%)$ & $11(29.7 \%)$ \\
\hline Obesity & $23(30.3 \%)$ & $11(29.7 \%)$ \\
\hline Diabetes & $8(10.5 \%)$ & $5(13.5 \%)$ \\
\hline VTE & $4(5.3 \%)$ & $3(8.1 \%)$ \\
\hline CAD & $3(3.9 \%)$ & $3(8.1 \%)$ \\
\hline History of cancer & $4(5.3 \%)$ & $2(5.4 \%)$ \\
\hline Baclofen pump & $3(3.9 \%)$ & $2(5.4 \%)$ \\
\hline Indwelling Foley & $3(3.9 \%)$ & $2(5.4 \%)$ \\
\hline None & $24(31.6 \%)$ & $12(32.4 \%)$ \\
\hline \multicolumn{3}{|l|}{ COVID-19 outcomes } \\
\hline Death, n (\%) & $6(7.9 \%)$ & $5(13.5 \%)$ \\
\hline Ongoing treatment/still recovering & $14(18.4 \%)$ & $7(18.9 \%)$ \\
\hline Recovered, n (\%) & 56 (73.7\%) & $25(67.6 \%)$ \\
\hline
\end{tabular}

Abbreviations: Anti-CD20 = ocrelizumab and rituximab; CAD = coronary artery disease; COVID-19 = coronavirus disease 2019; DMT = disease-modifying therapy; Interferons = interferon beta-1a and interferon beta-1b; IVIG = IV immunoglobulins; S1P inhibitors = fingolimod and siponimod; VTE = venous thromboembolism.

\section{Study funding}

No targeted funding reported.

\section{Disclosure}

E. Parrotta reports no disclosures. I. Kister served on advisory boards for Biogen and Genentech and received consulting fees from Roche and research support for investigatorinitiated grants from Sanofi Genzyme, Biogen, EMD Serono, National MS Society, and the Guthy-Jackson Charitable Foundation. L. Charvet reports no disclosures. C. Sammarco receives consulting compensation from Biogen and Genentech. V. Saha, R.E. Charlson, J. Howard, J.M. Gutman, M. Gottesman, N. Abou-Fayssal, R. Wolintz, M. Keilson, and C. Fernandez-Carbonell report no disclosures. L.B. Krupp has received advisory board/consulting fees, travel and meal allowances, and/or research funding from Sanofi Aventis, Biogen, Novartis, Gerson Lehrman, EMD Serono, Allergan Inc., and Tesaro Inc. She is also a noncompensated consultant and/or advisory board member with Novartis and Celgene and receives royalties for use of the Fatigue Severity Scale by various biopharmaceutical entities. L. Zhovtis Ryerson received personal compensation for advisory board participation for Biogen and received research support from Biogen. Go to Neurology.org/NN for full disclosures.

\section{Publication history}

Received by Neurology: Neuroimmunology \& Neuroinflammation May 11, 2020. Accepted in final form June 12, 2020.
Appendix Authors

\begin{tabular}{|c|c|c|}
\hline Name & Location & Contribution \\
\hline $\begin{array}{l}\text { Erica } \\
\text { Parrotta, DO }\end{array}$ & $\begin{array}{l}\text { NYU Langone } \\
\text { Comprehensive Care } \\
\text { Center, New York, NY }\end{array}$ & $\begin{array}{l}\text { Organization and } \\
\text { acquisition of data; } \\
\text { analyzed and interpreted } \\
\text { data; drafted results; and } \\
\text { revised the manuscript for } \\
\text { intellectual content }\end{array}$ \\
\hline $\begin{array}{l}\text { Ilya Kister, } \\
\text { MD }\end{array}$ & $\begin{array}{l}\text { NYU Langone } \\
\text { Comprehensive Care } \\
\text { Center, New York, NY }\end{array}$ & $\begin{array}{l}\text { Interpreted the data; } \\
\text { drafted the discussion; } \\
\text { and revised the } \\
\text { manuscript for intellectual } \\
\text { content }\end{array}$ \\
\hline $\begin{array}{l}\text { Leigh } \\
\text { Charvet, PhD }\end{array}$ & $\begin{array}{l}\text { NYU Langone } \\
\text { Comprehensive Care } \\
\text { Center, New York, NY }\end{array}$ & $\begin{array}{l}\text { Analyzed the data; } \\
\text { performed statistical } \\
\text { analysis; and revised the } \\
\text { manuscript for intellectual } \\
\text { content }\end{array}$ \\
\hline $\begin{array}{l}\text { Carrie } \\
\text { Sammarco, } \\
\text { DNP }\end{array}$ & $\begin{array}{l}\text { NYU Langone } \\
\text { Comprehensive Care } \\
\text { Center, New York, NY }\end{array}$ & $\begin{array}{l}\text { Major role in acquisition of } \\
\text { data }\end{array}$ \\
\hline $\begin{array}{l}\text { Valerie Saha, } \\
\text { NP }\end{array}$ & $\begin{array}{l}\text { NYU Langone } \\
\text { Comprehensive Care } \\
\text { Center, New York, NY }\end{array}$ & $\begin{array}{l}\text { Major role in acquisition of } \\
\text { data }\end{array}$ \\
\hline $\begin{array}{l}\text { Robert Erik } \\
\text { Charlson, } \\
\text { MD }\end{array}$ & $\begin{array}{l}\text { NYU Langone } \\
\text { Comprehensive Care } \\
\text { Center, New York, NY }\end{array}$ & Acquisition of data \\
\hline $\begin{array}{l}\text { Jonathan } \\
\text { Howard, MD }\end{array}$ & $\begin{array}{l}\text { NYU Langone } \\
\text { Comprehensive Care } \\
\text { Center, New York, NY }\end{array}$ & Acquisition of data \\
\hline
\end{tabular}


Appendix (continued)

\begin{tabular}{|c|c|c|}
\hline Name & Location & Contribution \\
\hline $\begin{array}{l}\text { Josef } \\
\text { Maxwell } \\
\text { Gutman, MD }\end{array}$ & $\begin{array}{l}\text { NYU Langone } \\
\text { Comprehensive Care } \\
\text { Center, Huntington, NY }\end{array}$ & Acquisition of data \\
\hline $\begin{array}{l}\text { Malcolm } \\
\text { Gottesman, } \\
\text { MD }\end{array}$ & $\begin{array}{l}\text { NYU Langone MS } \\
\text { Comprehensive Care } \\
\text { Center, Mineola, NY }\end{array}$ & Acquisition of data \\
\hline $\begin{array}{l}\text { Nada Abou- } \\
\text { Fayssal, MD }\end{array}$ & $\begin{array}{l}\text { NYU Langone } \\
\text { Comprehensive Care } \\
\text { Center, Brooklyn, NY }\end{array}$ & Acquisition of data \\
\hline $\begin{array}{l}\text { Robyn } \\
\text { Wolintz, MD }\end{array}$ & $\begin{array}{l}\text { NYU Langone } \\
\text { Comprehensive Care } \\
\text { Center, Brooklyn, NY }\end{array}$ & Acquisition of data \\
\hline $\begin{array}{l}\text { Marshall } \\
\text { Keilson, MD }\end{array}$ & $\begin{array}{l}\text { NYU Langone } \\
\text { Comprehensive Care } \\
\text { Center, Brooklyn, NY }\end{array}$ & Acquisition of data \\
\hline $\begin{array}{l}\text { Cristina } \\
\text { Fernandez- } \\
\text { Carbonell, } \\
\text { MD }\end{array}$ & $\begin{array}{l}\text { Cohen's Children Medical } \\
\text { Center Northwell Health, } \\
\text { Lake Success, NY }\end{array}$ & Acquisition of data \\
\hline
\end{tabular}

\section{References}

1. Luna G, Alping P, Burman J, et al. Infection risks among patients with multiple sclerosis treated with fingolimod, natalizumab, rituximab, and injectable therapies. JAMA Neurol 2020;77:184-191.
Appendix (continued)

\begin{tabular}{lll}
\hline Name & Location & Contribution \\
\hline $\begin{array}{l}\text { Lauren B. } \\
\text { Krupp, MD }\end{array}$ & $\begin{array}{l}\text { NYU Langone } \\
\text { Comprehensive Care } \\
\text { Center, New York, NY }\end{array}$ & $\begin{array}{l}\text { Interpreted the data and } \\
\text { drafted and revised the } \\
\text { manuscript for intellectual } \\
\text { content }\end{array}$ \\
\hline $\begin{array}{l}\text { Lana Zhovtis } \\
\text { Ryerson, MD }\end{array}$ & $\begin{array}{l}\text { NYU Langone } \\
\text { Comprehensive Care } \\
\text { Center, New York, NY }\end{array}$ & $\begin{array}{l}\text { Designed and } \\
\text { conceptualized the study; } \\
\text { analyzed the data; and } \\
\text { drafted and revised the } \\
\text { manuscript for intellectual } \\
\text { content }\end{array}$ \\
& &
\end{tabular}

2. Mehta P, McAuley DF, Brown M, Sanchez E, Tattersall RS, Manson JJ. COVID-19: consider cytokine storm syndromes and immunosuppression. The Lancet 2020;395: 1033-1034.

3. Available at: cdc.gov/coronavirus/2019-nCoV/hcp/index.html. Accessed May 4, 2020

4. Sormani MP. An Italian programme for COVID-19 infection in multiple sclerosis. Lancet Neurol 2020;19:481-482.

5. Zhou F, Yu T, Du R, et al. Clinical course and risk factors for mortality of adult inpatients with COVID-19 in Wuhan, China: a retrospective cohort study. Lance 2020;395:1054-1062.

6. Lighter J, Phillips M, Hochman S, et al. Obesity in patients younger than 60 years is a risk factor for Covid-19 hospital admission. Clin Infect Dis Epub 2020 Apr 9.

7. Petrilli CM, Jones SA, Yang J, et al. Factors associated with hospitalization and critical illness among 4,103 patients with COVID-19 disease in New York City. BMJ 2020;369:m 1966

8. Richardson S, Hirsch JS, Narasimhan M, et al. Presenting characteristics, comorbidities, and outcomes among 5700 patients hospitalized with COVID-19 in the New York City area. JAMA 2020;323:2052-2059. 


\title{
Neurology \\ Neuroimmunology \& Neuroinflammation
}

\author{
COVID-19 outcomes in MS: Observational study of early experience from NYU \\ Multiple Sclerosis Comprehensive Care Center \\ Erica Parrotta, Ilya Kister, Leigh Charvet, et al. \\ Neurol Neuroimmunol Neuroinflamm 2020;7; \\ DOI 10.1212/NXI.0000000000000835
}

This information is current as of July 9, 2020

\section{Updated Information \& Services}

References

Citations

Subspecialty Collections

Permissions \& Licensing

Reprints including high resolution figures, can be found at: http://nn.neurology.org/content/7/5/e835.full.html

This article cites 5 articles, 0 of which you can access for free at: http://nn.neurology.org/content/7/5/e835.full.html\#\#ref-list-1

This article has been cited by 6 HighWire-hosted articles: http://nn.neurology.org/content/7/5/e835.full.html\#\#otherarticles

This article, along with others on similar topics, appears in the following collection(s):

All Demyelinating disease (CNS)

http://nn.neurology.org//cgi/collection/all_demyelinating_disease_cns COVID-19

http://nn.neurology.org//cgi/collection/covid_19

Multiple sclerosis

http://nn.neurology.org//cgi/collection/multiple_sclerosis

Information about reproducing this article in parts (figures,tables) or in its entirety can be found online at:

http://nn.neurology.org/misc/about.xhtml\#permissions

Information about ordering reprints can be found online: http://nn.neurology.org/misc/addir.xhtml\#reprintsus

Neurol Neuroimmunol Neuroinflamm is an official journal of the American Academy of Neurology.

Published since April 2014, it is an open-access, online-only, continuous publication journal. Copyright Copyright (C) 2020 The Author(s). Published by Wolters Kluwer Health, Inc. on behalf of the American Academy of Neurology.. All rights reserved. Online ISSN: 2332-7812.

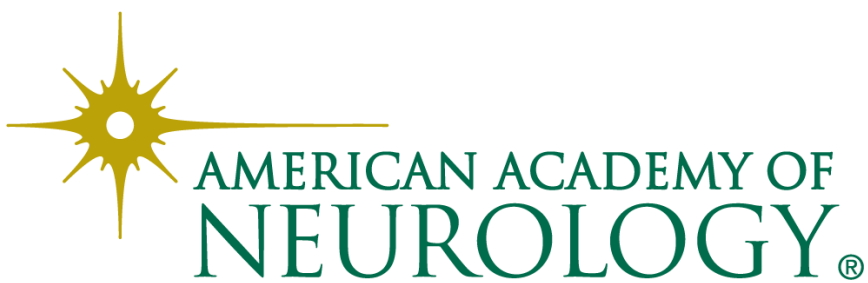

